\title{
Magonia pubescens (Sapindaceae) Seed Oil: Physical and Chemical Properties, Fatty Acid Profile and Biodiesel Production
}

\author{
Juliana Almeida Rocha ${ }^{1,2}$, Elytania Veiga Menezes ${ }^{2}$, Francine Souza Alves Fonseca ${ }^{3}$, Murilo Malveira Brandão ${ }^{2}$, \\ Kamylla Teixeira Santos ${ }^{1,2}$, Dario Alves de Oliveira ${ }^{2}$, Afrânio Farias de Melo Júnior ${ }^{2}$ \\ \& Vanessa de Andrade Royo ${ }^{1,2}$ \\ ${ }^{1}$ Laboratory of Natural Products, State University of Montes Claros, Campus Darcy Ribeiro, Vila Mauriceia, \\ Montes Claros, MG, Brazil \\ ${ }^{2}$ Laboratory Bioprospecting and Genetic Resources, State University of Montes Claros, Campus Darcy Ribeiro, \\ Vila Mauriceia, Montes Claros, MG, Brazil \\ ${ }^{3}$ Laboratory of Medicinal Plants of the Institute of Agricultural Sciences, Federal University of Minas Gerais, \\ Universitário, Montes Claros, MG, Brazil \\ Correspondence: Vanessa de Andrade Royo, Laboratory of Natural Products, State University of Montes Claros, \\ Campus Darcy Ribeiro, Vila Mauriceia, Montes Claros, MG, Brazil. Tel: 55-383-229-8342. E-mail: \\ vanroyo31@gmail.com
}

Received: July 31, 2017

Accepted: August 23, $2017 \quad$ Online Published: September 15, 2017

doi:10.5539/jas.v9n10p178

URL: https://doi.org/10.5539/jas.v9n10p178

\begin{abstract}
Magonia pubescens is a tree species originally from the Brazilian Cerrado that bears fruit with winged seeds from which fixed oil can be extracted. This study aimed to analyze the physical and chemical properties of the oil extracted from these seeds and the biodiesel produced thereof. Methods from the Adolfo Lutz Institute, American Oil Chemists Society, and American Society for Testing and Materials were used. Seven fatty acids (oleic, arachidic, gadoleic, palmitic, palmitoleic, linoleic, and stearic acids) were found in the oil. Acidity level $\left(1.119 \mathrm{mg} \mathrm{KOH} \cdot \mathrm{g}^{-1}\right)$, iodine value $\left(77.36 \mathrm{cg} \mathrm{I} \cdot \mathrm{g}^{-1}\right)$, saponification value $\left(133.36 \mathrm{mg} \mathrm{KOH} \cdot \mathrm{g}^{-1}\right)$, density $(0.8796$ $\left.\mathrm{g} \cdot \mathrm{cm}^{-3}\right)$, and refractive index $(1.3348 \mathrm{nD})$ were low when compared to the high peroxide value $\left(26.14 \mathrm{meq} \cdot \mathrm{kg}^{-1}\right)$, viscosity $\left(101.46 \mathrm{~mm}^{2} \cdot \mathrm{s}^{-1}\right)$, and moisture $(0.88 \%)$ of other oils and fats used for biodiesel production. Biodiesel showed density $\left(0.8484 \mathrm{~g} \cdot \mathrm{cm}^{-3}\right)$, viscosity $\left(29.62 \mathrm{~mm}^{-2} \cdot \mathrm{s}^{-1}\right)$, acidity level $\left(0.752 \mathrm{mg} \mathrm{KOH} \cdot \mathrm{g}^{-1}\right)$, and saponification value $\left(148.89 \mathrm{mg} \mathrm{KOH} \cdot \mathrm{g}^{-1}\right)$.
\end{abstract}

Keywords: fatty acids, cerrado, winged seeds, oleaginous seeds, Tingui

\section{Introduction}

Magonia pubescens (Sapindaceae), known as "Tingui", "Timbo", and "Tingui do Cerrado", is a plant originally from the Brazilian Cerrado also found in Bolivia and Paraguay. It is between four and twelve meters tall, and bears large, globular fruit with winged seeds, which germinate easily. This species is used for initial reforestation of degraded lands, its seeds are used to produce soap, and oil can be extracted there of (Coelho et al., 2012).

Biodiesel is a fuel consisting of methyl or ethyl esters obtained by transesterification of different oil sources such as edible and inedible oils, animal fat, algae, and reused oils (Canoira et al., 2010). This type of biofuel production is important, because it can be a substitute for diesel oil, whose reserves have reduced. It is considered a renewable fuel, sinceits oily raw material could be restored by the cultivation of oleaginous plants and/or fat from slaughtered animals. The production of biodiesel can potentially reduce the dependence on oil import to countries with no oil reserves and contribute to local agricultural industries. Moreover, it is miscible in diesel oil in different ratios, causing no damage to engines. It has reduced sulfur content, adequate flash point and lubricity, and shows positive energy balance (Blin et al., 2013; Knothe, 2002; Rakopoulos et al., 2015).

The production of quality biodiesel depends on the correct selection of the oil sources used, since their physical and chemical properties determine biofuel properties. The analysis of inputs should allow selection of the best options and produce a high-quality end product. The properties of the chemical structures of fats and oils that contribute to biodiesel quality are mainly length, degree of unsaturation, and branching chain of their fatty acids. 
In this manner, most of the tests used to evaluate the physical and chemical properties in oil and biodiesel are based on indexes determined by the properties above (Martinez et al., 2014).

Seeking new oil sources for biodiesel production is important, since most oils used for its production are also used in foodstuffs. Therefore, low-cost oil sources that are not used as foodstuff, have appropriate physical and chemical properties, and are locally available should be indetified (Martinez et al., 2014). In the Brazilian context, the use of genetic resources of the Cerrado to develop new products contributes to the exploitation and preservation of species and increases the income of local communities. The seed oil from M. pubescens may represent an innovative source for biodiesel production, without posing a risk of reducing the supply of oil for food. In this manner, this study aimed principally to analyze the potential use of these seed oils for biodiesel production.

\section{Method}

The fruits and seeds were collected from July to September 2014 directly from M. pubescens trees in the Cerrado biome in the city of Montes Claros, Minas Gerais, Brazil. The species was identified based on a voucher specimen labeled as number 106750 in the Herbarium at the Institute of Biological Sciences, Federal University of Minas Gerais in Belo Horizonte, Minas Gerais.

The seeds were first peeled and then dried at $105 \pm 2{ }^{\circ} \mathrm{C}$ for 24 hours in an oven (Nova Ética, model 400-4ND). The cold-pressed oil was mechanically extracted using a hydraulic press. The extraction yield was calculated as a percentage of the weight of seed used.

\subsection{Analysis of Seeds, Oil, and Biodiesel}

The moisture content in the seeds was analyzed according to methods provided by the Adolfo Lutz Institute (IAL, 2008). The moisture content, density, ash content, peroxide value, saponification value, viscosity and refraction index of the oil were analyzed according to methods of the American Oil Chemists Society (AOCS). The density analysis and acidity level testing of the biodiesel followed the standards of the American Society for Testing and Materials (ASTM).

\subsection{Complementary Analyses of Oil and Biodiesel}

Some complementary analyses were carried out using methods different from those provided by the AOCS and ASTM.

\subsubsection{Iodine Value (Oil)}

The iodine value was calculated based on the composition of fatty acids with unsaturated bonds and their ratio in the oil composition, obtained by gas chromatography analysis, using the Equation 1 (Knothe, 2002).

$$
I I_{\text {oil }}=\Sigma 100 \times \frac{A f \times 253.81 \times d b}{M W F}
$$

Where,

$I I=$ iodine value; $A f=$ the percentage of fatty acid in the composition; $253.81=$ weight of two iodine atoms that are theoretically added to a double bond; $d b=$ number of unsaturated bonds of the fatty acid; $M W F=$ molecular weight of fatty acid.

\subsubsection{Composition of Fatty Acids}

The oil composition of fatty acids was analyzed using a gas chromatograph model 7890A GC system (Agilent Technologies, Santa Clara, CA, USA) coupled to a mass spectrometer model 5975C inert XL MSD with triple-axis detector (Agilent Technologies, Santa Clara, CA, USA). The esters were identified by comparing the mass spectrum previously found with the NIST 2.0 library standards Chemstation software (Agilent Technologies, Santa Clara, CA, USA).

Firstly, an oil sample was subjected to derivatization. The process was carried out by adding $20 \mathrm{mg}$ of oil to 5 $\mathrm{mL}$ of potassium hydroxide solution at $0.5 \mathrm{~mol} \cdot \mathrm{L}^{-1}$. The mixture was heated under reflux and stirred constantly for one hour. Subsequently, $2 \mathrm{~mL}$ of $4: 1 \mathrm{v} / \mathrm{v}$ hydrochloric acid/methanol was added and the solution was heated under reflux for another hour. After reaching room temperature, $5 \mathrm{~mL}$ of distilled water was added. For extraction, three aliquots of $5 \mathrm{~mL}$ of dichloromethane were added to the material obtained from derivatization. The organic phase was collected and then anhydrous sodium sulfate was added to remove water. The resulting mixture was filtered through a round-bottom flask and evaporated in a rotary evaporator at $65^{\circ} \mathrm{C}$. The material was solubilized again using dichloromethane as a solvent and placed in a previously weighed penicillin bottle. After spontaneous evaporation of all dichloromethane in a desiccator at room temperature, the yield was 
calculated. For analysis of the chemical composition, $20 \mu \mathrm{L}$ of the methylated oil was diluted in $980 \mu \mathrm{L}$ of dichloromethane and then GC-MS analysis was carried out.

The carrier gas used was Helium 6.0; flow rate of $1.8 \mathrm{~mL}$ per minute. The sample injection temperature was $220^{\circ} \mathrm{C}$. The split ratio was $1: 10$. The initial temperature of the column was $160{ }^{\circ} \mathrm{C}$ for two minutes, then $200{ }^{\circ} \mathrm{C}$ at a rate of $2{ }^{\circ} \mathrm{C}$ per minute, then $240{ }^{\circ} \mathrm{C}$ at a rate of $10^{\circ} \mathrm{C}$ per minute. The total analysis lasted 26 minutes. The interface temperature was $240^{\circ} \mathrm{C}$ and the programmed mass/charge ratio was from 30 to 600 (Adams, 2007).

\subsection{Biodiesel Production}

The biodiesel was produced by single-step transesterification. The molar ratio of the reaction was 1 mol of oil to $6 \mathrm{~mol}$ of alcohol (methanol) and $1.5 \%$ potassium hydroxide as a catalyst per mass of oil. The reaction was constantly stirred and heated under reflux $\left(40\right.$ to $\left.45^{\circ} \mathrm{C}\right)$ for 50 minutes. The biodiesel obtained was washed with distilled water $\left(80^{\circ} \mathrm{C}\right)$ until a neutral $\mathrm{pH}$ was achieved and then dried in an oven until all traces of water and turbidity disappeared (Martínez et al., 2014; Mendow et al., 2011; Santos et al., 2013).

\section{Results and Discussions}

The moisture content foundin cotyledons was $5.48 \%$ and in seeds $7.03 \%$. The moisture content in seeds is close to that found in seeds of the same species collected in the Cerrado of the state of Mato Grosso (6.39\%) (Coelho et al., 2012). The moisture content was considered suitable for oil extraction for biodiesel production since the moisture content of seeds should beless than $9 \%$ for this purpose (Sidibé et al., 2010).

The yield obtained in the extraction of oil from seeds was $10.36 \%$. The quantity of oil extracted may vary due to the type of press used, moisture content, and prior processes for cleaning and heating the seeds (Sidibé et al., 2010).

The analysis of seed oil using a gas chromatograph coupled to a mass spectrometer (GC-MS) identified seven fatty acids in the seed oil of M. pubescens (Figure 1). The fatty acid profile of vegetable oils usually consists of five acids, namely, palmitic, stearic, oleic, linoleic, and linolenic (Knothe et al., 2002). Most of these fatty acids can be found in the seed oil of M. pubescens (Table 1).

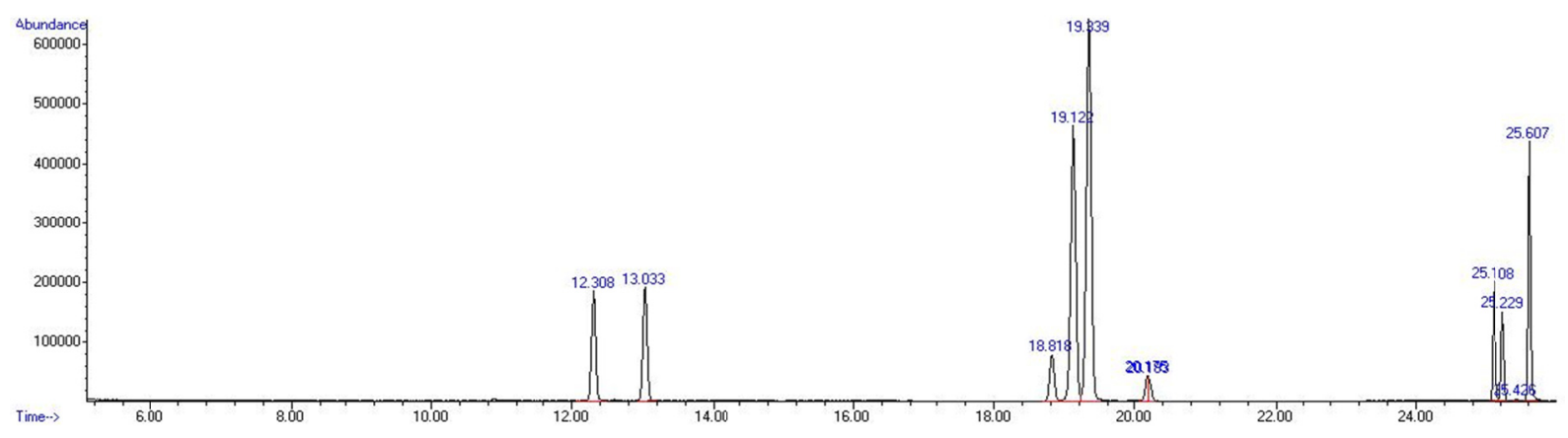

Figure 1. Chromatogram M. pubescens seeds oil obtained by GC-MS 
Table 1. Fatty acid composition in M. pubescens oil and other oils

\begin{tabular}{|c|c|c|c|c|c|c|c|c|c|}
\hline \multirow[b]{2}{*}{ Source } & \multicolumn{8}{|c|}{ Fatty acids (\%) } & \multirow[b]{2}{*}{ Ref. } \\
\hline & $\begin{array}{l}\text { Palmitoleic } \\
\text { (C16:1) }\end{array}$ & $\begin{array}{l}\text { Palmitic } \\
\text { (C16:0) }\end{array}$ & $\begin{array}{l}\text { Linoleic } \\
(\mathrm{C} 18: 2)\end{array}$ & $\begin{array}{l}\text { Oleic } \\
(\mathrm{C} 18: 1)\end{array}$ & $\begin{array}{l}\text { Stearic } \\
(\mathrm{C} 18: 0)\end{array}$ & $\begin{array}{l}\text { Gadoleic } \\
(\mathrm{C} 20: 1)\end{array}$ & $\begin{array}{l}\text { Arachidic } \\
(\mathrm{C} 20: 0)\end{array}$ & Others & \\
\hline M. pubescens & 8 & 8.2 & 3.7 & 56.9 & 2.4 & 9.5 & 11.3 & - & - \\
\hline \multirow{4}{*}{ Soybean } & 0.11 & 10.26 & 51.04 & 26.55 & 3.52 & - & 0.23 & 8.29 & $-\overline{(1)}$ \\
\hline & 0.2 & 11.2 & 55.4 & 25.2 & 2.9 & 0.1 & - & 5 & \multirow{3}{*}{$\begin{array}{l}\text { (2) } \\
(3) \\
(4)\end{array}$} \\
\hline & 0.11 & 11.6 & 52.93 & 25.09 & 3.25 & - & - & 7.02 & \\
\hline & 0.10 & 10.47 & 53.28 & 24.96 & 3.34 & - & - & 7.85 & \\
\hline Cotton & - & 28.7 & 57.4 & 13.0 & 0.9 & - & - & - & $-\overline{4})$ \\
\hline \multirow{3}{*}{ Sunflower } & 0.12 & 5.33 & 52.01 & 37.13 & 3.45 & - & 0.16 & 1.8 & \multirow{3}{*}{$\begin{array}{l}\text { (2) } \\
(5)\end{array}$} \\
\hline & 0.3 & 6.7 & 51.3 & 38.7 & 2.9 & 0.1 & - & - & \\
\hline & 0.09 & 6.14 & 51.17 & 34.30 & 4.11 & - & 0.17 & 1.02 & \\
\hline \multirow{2}{*}{ Palm } & 0.4 & 45.6 & 10.5 & 38.5 & 3.8 & - & - & 1.2 & \multirow{2}{*}{$\begin{array}{l}(\overline{2}) \\
\text { (4) }\end{array}$} \\
\hline & 0.19 & 43.03 & 10.82 & 39.47 & 4.31 & - & - & 2.18 & \\
\hline Animal fat & 3.32 & 29.06 & 1.8 & 35.92 & 23.82 & - & - & 6.08 & $(\overline{4})$ \\
\hline Beef tallow & 2.86 & 22.99 & 3.91 & 41.6 & 19.44 & 0.33 & 0.14 & 8.73 & $(6)^{-}$ \\
\hline Canola & 0.27 & 6.45 & 29.81 & 53.36 & 2.54 & - & 0.42 & 7.15 & ${ }^{-1}(\overline{1})^{-}$ \\
\hline Jatropha oil & 1.07 & 13.95 & 33.78 & 42.71 & 7.94 & - & - & 0.55 & $-\overline{3})^{-}$ \\
\hline Castor oil & - & 1.64 & 6.42 & 82.88 & 1.85 & 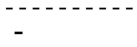 & - & 2.18 & $-\overline{7})^{-}$ \\
\hline
\end{tabular}

Note. References: ${ }^{(1)}$ Atmanli et al. (2015); ${ }^{(2)}$ Esteban et al. (2012); ${ }^{(3)}$ Martínez et al. (2014); ${ }^{(4)}$ Melero et al. (2010); ${ }^{(5)}$ Ghanei et al. (2011); ${ }^{(6)}$ Goodrum et al. (2003); ${ }^{(7)}$ Canoira et al. (2010).

On comparing M. pubescens oil with other oily inputs used for biodiesel production (Table 1), it is possible to observe that oleic acid is the main acid found in this oil (56.9\%), and is the second most frequently found in soybean oil $(25.09 \%$ to $26.55 \%)$. Arachidic acid (11.3\%) and gadoleic acid (9.5\%) are, respectively, the second and third most prevalent in M. pubescens oil, although they represent less than $1 \%$ of fatty acids in soybean oil. On the other hand, linoleic acid, whose content in soybean oil is higher, ranging from $51.04 \%$ to $55.4 \%$, is lower in M. pubescens oil (3.7\%).

The palmitic acid found in M. pubescens oil (8.2\%) is also found in palm oil, although at higher levels (43.03\% and $45.6 \%$ ) in the latter. Oleic acid is abundantly found in M. pubescens oil (56.9\%), while it is the second most commonly found (38.5\% to $39.47 \%$ ) in palm oil. The linoleic acid found in $M$. pubescens oil (3.7\%) is the main fatty acid in sunflower oil $(51.17 \%$ to $52.01 \%)$. Cotton seed oil also has a great quantity of this fatty acid $(57.4 \%)$.

Oleic acid is a major component in M. pubescens oil (56.9\%), castor oil (82.88\%), canola oil (53.36\%), jatropha oil $(42.71 \%$ ), and animal fat (35 92\% to $41.6 \%$ ). The latter also has considerable amounts of palmitic acid ( $22.99 \%$ to $29.06 \%)$ and stearic acid $(19.44 \%$ to $23.82 \%$ ), which are also found in M. pubescens oil, but in smaller quantities, $8.2 \%$ and $2.4 \%$, respectively (Table 1 ).

\subsection{Physical and Chemical Properties of M. pubescens Oil}

Physical and chemical properties of oils are determined by their conservation status, chain length, and degree of unsaturation of their fatty acids. Some properties are related to only one of these properties, e.g., the iodine number, which depends on the degree of unsaturation and the saponification value, which is determined by the carbon chain length. The combination of degree of unsaturation and chain length is critical for density, viscosity, and refraction. The oil conservation status can be assessed by tests such as acidity value and peroxide value.

\subsubsection{Saponification and Iodine Value}

M. pubescens oil has a lower saponification value $\left(133.36 \mathrm{mg} \mathrm{KOH} \cdot \mathrm{g}^{-1}\right)$ compared with other oils used as raw materials for biodiesel production, such as soybean (190.1 to $194.2 \mathrm{mg} \mathrm{KOH} \cdot \mathrm{g}^{-1}$ ), animal fat (196.3 to $195.7 \mathrm{mg}$ $\mathrm{KOH} \cdot \mathrm{g}^{-1}$ ), palm (199.1 to $\left.200.1 \mathrm{mg} \mathrm{KOH} \cdot \mathrm{g}^{-1}\right)$, canola $\left(184.0\right.$ to $\left.191.0 \mathrm{mg} \mathrm{KOH} \cdot \mathrm{g}^{-1}\right)$, and sunflower $(187.7$ to $\left.195.3 \mathrm{mg} \mathrm{KOH} \cdot \mathrm{g}^{-1}\right)$, and is also lower than linseed $\left(179.4 \mathrm{mg} \mathrm{KOH} \cdot \mathrm{g}^{-1}\right)$ and acai $\left(189.1 \mathrm{mg} \mathrm{KOH} \cdot \mathrm{g}^{-1}\right)$, as shown in Table 2. 
Table 2. Saponification and iodine index M. pubescens oil and other oils

\begin{tabular}{|c|c|c|}
\hline Source & Saponification index $\left({\left.\mathrm{mg} \mathrm{KOH} \cdot \mathrm{g}^{-1}\right)}\right.$ & Iodine index $\left(\mathrm{cg} \mathrm{I}_{2} \cdot \mathrm{g}^{-1}\right)$ \\
\hline M. pubescens & $133.36( \pm 0.2406)$ & 77.36 \\
\hline Soybean & $193.2^{(1)} ; 194.2^{\mathrm{a}(2)} ; 190.1^{\mathrm{b}(2)}$ & $119.8^{(1)} ; 119.6^{\mathrm{a}(2)} ; 123.7^{\mathrm{b}(2)} ; 120.52^{(6)} ; 120-143^{(7)}$ \\
\hline Palm & $200.1^{\mathrm{a}(2)} ; 199.1^{\mathrm{b}(2)}$ & $52.5^{\mathrm{a}(2)} ; 47.8^{\mathrm{b}(2)}$ \\
\hline Beef tallow & $196.3^{(2)}$ & $40.6^{(8)} ; 42.2^{(2)} ; 45.3^{(9)}$ \\
\hline Pork fat & $195.7^{(2)}$ & $44.8^{(2)} ; 77.9^{(9)}$ \\
\hline Castor oil & $181.85^{(3)}$ & $83.51^{(3)}$ \\
\hline Canola & $184.0^{(1)} ; 191.0^{(2)}$ & $111.7^{(2)} ; 101.1^{(1)}$ \\
\hline Sunflower & $187.7^{(1)} ; 193.5^{(2)} ; 195.3^{(4)}$ & $93.5^{(1)} ; 111.2^{(2)}$ \\
\hline Linssed & $179.4^{(5)}$ & $180.1^{(5)}$ \\
\hline Açaí & $189.1^{(5)}$ & $61.8^{(5)}$ \\
\hline
\end{tabular}

Note. ${ }^{a}$ Unrefined; ${ }^{b}$ Refined. References: ${ }^{(1)}$ Martínez et al. (2014); ${ }^{\left({ }^{2}\right)}$ Toscano et al. (2012); ${ }^{(3)}$ Canoira et al. (2010); ${ }^{(9)}$ Mata et al. (2011).

M. pubescens oil consists of $20.8 \%$ fatty acids such as gadoleic and arachidic containing 20 carbon atoms. The presence of long chain fatty acids justifiesa lower saponification value when compared with soybean, canola, sunflower, and animal fats that have fewer long chain fatty acids (Table 1).

The iodine value of $M$. pubescens oil $\left(77.36 \mathrm{I}_{2} \cdot \mathrm{g}^{-1}\right)$ is lower than those found in the literature for soybean (119.6 to $143 \mathrm{I}_{2} \cdot \mathrm{g}^{-1}$ ), canola $\left(101,1\right.$ to $\left.111.7 \mathrm{I}_{2} \cdot \mathrm{g}^{-1}\right)$, sunflower (93.5 to $\left.111.2 \mathrm{I} 2 \cdot \mathrm{g}^{-1}\right)$, and linseed oils $\left(180.1 \mathrm{I}_{2} \cdot \mathrm{g}^{-1}\right)$. However, it is higher than those found in beef tallow (40.6 to $45.3 \mathrm{I}_{2} \cdot \mathrm{g}^{-1}$ ), pork lard (44.8 to $77.9 \mathrm{I}_{2} \cdot \mathrm{g}^{-1}$ ), palm oil (47.8 to $\left.52.5 \mathrm{I}_{2} \cdot \mathrm{g}^{-1}\right)$, and acai oil $\left(61.8 \mathrm{I}_{2} \cdot \mathrm{g}^{-1}\right)$ (Table 2).

Table 1 shows that $M$. pubescens oil has seven fatty acids and four of them are slightly unsaturated (palmitoleic, linoleic, oleic, and gadoleic). However, only linoleic acid has two double bonds and represents only $3.7 \%$ of the fatty acids. The remaining three fatty acids have only one degree of unsaturation. When compared with other oils, the fatty acid composition may have contributed to alower iodine value, as linoleic acid, which is unsaturated, is abundantly found in soybean $(51.04 \%$ to $55,4 \%)$ and sunflower oil $(51.17 \%$ to $52.01 \%)$, which presented higher iodine indexes than M. pubescens oil.

\subsubsection{Acidity Level, Peroxide Value, and Moisture Content}

The acidity level of $M$. pubescens oil $\left(1.119 \mathrm{mg} \mathrm{KOH} \cdot \mathrm{g}^{-1}\right)$ is suitable for biodiesel production. Although there are no official regulations for properties of oils used as raw material for biodiesel production, the acidity level is expected to be below $2 \mathrm{mg} \mathrm{KOH} \cdot \mathrm{g}^{-1}$ (Kwiecien et al., 2009).

Table 3 shows that the acidity level of M. pubescens oil is higher than soybean $\left(0.069\right.$ to $\left.0.39 \mathrm{mg} \mathrm{KOH} \cdot \mathrm{g}^{-1}\right)$, castor $\left(0.56 \mathrm{mg} \mathrm{KOH} \cdot \mathrm{g}^{-1}\right)$, and canola oils $\left(0.71\right.$ to $\left.0.89 \mathrm{mg} \mathrm{KOH} \cdot \mathrm{g}^{-1}\right)$. However, its acidity level is lower than sunflower oil $\left(1.90 \mathrm{mg} \mathrm{KOH} \cdot \mathrm{g}^{-1}\right)$, palm oil $\left(11.6 \mathrm{mg} \mathrm{KOH} \cdot \mathrm{g}^{-1}\right)$, and animal fat $\left(2.56\right.$ to $\left.7.0 \mathrm{mg} \mathrm{KOH} \cdot \mathrm{g}^{-1}\right)$. 
Table 3. Acidity index, humidity and peroxide index M. pubescens oil and others oils

\begin{tabular}{|c|c|c|c|}
\hline Source & 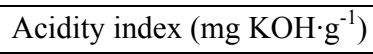 & Humidity $(\%)$ & Peroxide index $\left(\mathrm{meq} \cdot \mathrm{Kg}^{-1}\right)$ \\
\hline M. pubescens & $1.119( \pm 0.1933)$ & $0.88( \pm 0.0560)$ & $26.14( \pm 5.9967)$ \\
\hline Soybean & $0.069^{(1)} ; 0.099^{(2)} ; 0.039^{(3)}$ & $0.07^{(5)}$ & $0^{(9)} ; 0.01^{(9)} ; 3.21^{(10)}$ \\
\hline Fat & $2.56^{(1)} ; 7.0^{(4)}$ & - & - \\
\hline Palm & $11.6^{(1)}$ & - & $0.6-2.19^{a(11)}$ \\
\hline Sunflower & $1.90^{(5)}$ & $0.07^{(8)} ; 0.06^{(5)}$ & $0.99^{(10)}$ \\
\hline Castor oil & $0.56^{(6)}$ & - & - \\
\hline Canola & $0.71^{(5)} ; 0.89^{(7)}$ & - & - \\
\hline Rapeseed & - & $0.06^{(5)}$ & - \\
\hline Jatropha oil & - & $0.1^{(5)}$ & - \\
\hline Corn & - & - & $1.0^{(10)}$ \\
\hline Linseed & - & - & $10^{(12)} ; 5.2^{(13)}$ \\
\hline Acai & - & - & $177.1^{(12)}$ \\
\hline
\end{tabular}

The moisture content found in $M$. Pubescens oil is $0.88 \%$. It is high when compared to those found in soybean $(0.07 \%)$, sunflower $(0.06$ to $0.07 \%)$, rapeseed $(0.06 \%)$, and jatropha oil $(0.1 \%)$ (Table 3$)$. High moisture content can contribute to an increased acidity level, as it facilitates the hydrolysis of triglycerides and, consequently, the formation of free fatty acids, which can result in oil degradation (Almeida et al., 2013; Blin et al., 2013).

The peroxide value found in $M$. pubescens oil $\left(26.139 \mathrm{meq} \cdot \mathrm{kg}^{-1}\right)$ was higher than that found in the literature for soybean $\left(0\right.$ to $\left.3.21 \mathrm{meq} \cdot \mathrm{kg}^{-1}\right)$ and palm oils $\left(0.6\right.$ to $\left.2.19 \mathrm{meq} \cdot \mathrm{kg}^{-1}\right)$, which are raw materials considered of great importance for biodiesel production. The only oil that showed a peroxide value greater than that of $M$. pubescens was acai $\left(177.1 \mathrm{meq} \cdot \mathrm{kg}^{-1}\right)$ (Table 3). The peroxide value is related to storage time, temperature, exposure to light, foreign materials, the extraction process used to extract the oil, and may also vary depending on the origin of seeds used in the extraction process (Almeida et al., 2013; Mata et al., 2011; Pantoja et al., 2013; Sidibé et al., 2010).

Analyses were carried out immediately after oil extraction, so the high peroxide value found is not related to storage time, but may be related to the extraction process employed. In this manner, it is important to carry out studies for the evaluation of other extraction processes, in order to obtain oils with lower peroxide values.

\subsubsection{Viscosity Index, Density, Refractive Index, and Ash Content}

The viscosity index at $20^{\circ} \mathrm{C}$ of $M$. pubescens oil was $101.46 \mathrm{~mm}^{2} \cdot \mathrm{s}^{-1}$. This index is higher than those found in the literature for soybean $\left(67.12 \mathrm{~mm}^{2} \cdot \mathrm{s}^{-1}\right)$, cotton $\left(34.0 \mathrm{~mm} \cdot \mathrm{s}^{-1}\right)$, palm $\left(79.7 \mathrm{~mm}^{2} \cdot \mathrm{s}^{-1}\right)$, rapeseed $\left(74.19 \mathrm{~mm}^{2} \cdot \mathrm{s}^{-1}\right)$, sunflower $\left(64.4\right.$ to $\left.73.45 \mathrm{~mm}^{2} \cdot \mathrm{s}^{-1}\right)$, corn $\left(70.29 \mathrm{~mm}^{2} \cdot \mathrm{s}^{-1}\right)$, acai $\left(50.1 \mathrm{~mm}^{2} \cdot \mathrm{s}^{-1}\right)$, and linseed oils $\left(26.7 \mathrm{~mm}^{2} \cdot \mathrm{s}^{-1}\right)$. However, it may be considered lower than that of beef tallow, whichis solid up to $40^{\circ} \mathrm{C}$ (Table 4). 
Table 4. Viscosity $20^{\circ} \mathrm{C}$, specific mass $20^{\circ} \mathrm{C}$ and refractive index M. pubescens oil and others oils

\begin{tabular}{llll}
\hline Source & Viscosity $\left(\mathrm{mm}^{2} \cdot \mathrm{s}^{-1}\right)$ & Specific mass $\left(\mathrm{g}^{\circ} \mathrm{cm}^{-3}\right)$ & Refractive index $(\mathrm{nD})$ \\
\hline M. pubescens & $101.46( \pm 0.0002)$ & $0.8796( \pm 0.00015)$ & $1.3348( \pm 0.00028)$ \\
Soybean & $60.5^{(1)} ; 67.12^{(2)}$ & $0.9185^{(2)} ; 0.920^{(7)} ; 0.9237^{(8)} ; 0.931^{(3)}$ & $1.4671^{(9,10)} ; 1.4680^{(11)}$ \\
Sunflower & $64.4^{(1)} ; 73.45^{(2)}$ & $0.9169^{(2)} ; 0.932^{(3)}$ & $1.4668^{(12)} ; 1.4679^{(10)}$ \\
Palm & $79.70^{(3)}$ & $0.917^{(3)} ; 0.928^{(7)}$ & - \\
Fat & Solid ${ }^{(4)}$ & $0.909^{(7)} ; \pm 0.91^{\mathrm{a}(4)}$ & - \\
Cotton & $30.4^{(5)}$ & $0.910^{(5)}$ & - \\
Rapeseed & $74.19^{(2)}$ & $0.9145^{(2)}$ & - \\
Canola & - & $0.917^{(3)}$ & - \\
Corn & $70.29^{(2)}$ & $0.9167^{(2)}$ & - \\
Acai & $50.1^{(6)}$ & - & $1.4657^{(10)}$ \\
Linseed & $26.7^{(6)}$ & - & - \\
Castor oil & - & $1.4792^{(14)}$ & -
\end{tabular}

Note. References: ${ }^{(1)}$ Quinchia et al. (2010); ${ }^{(2)}$ Esteban et al. (2012); ${ }^{(3)}$ Siddique et al. (2010); ${ }^{(4)}$ Goodrum et al. (2003); ${ }^{(5)}$ Rakopoulos et al. (2015); ${ }^{(6)}$ Pantoja et al. (2013); ${ }^{(7)}$ Melero et al. (2010); ${ }^{(8)}$ Santos et al. $(2013) ;{ }^{(9)}$ Moradi et al. (2012); ${ }^{(10)}$ Jorge et al. (2005); ${ }^{(11)}$ Santos et al. (2013); ${ }^{(12)}$ Ghanei et al. (2011); ${ }^{(13)}$ Bera et al. (2006); ${ }^{(14)}$ Canoira et al. (2010). ${ }^{\text {a }}$ Measured at $40{ }^{\circ} \mathrm{C}$ as it is solid at that temperature.

The viscosity index increases when the chain length of fatty acids increases and decreases when the number of unsaturated bonds increases (Esteban et al., 2012; Siddique et al., 2010; Toscano et al., 2012). Thus, the viscosity index found in M. pubescens oil is due to the amount of gadoleic acid (9.5\%) and arachidic acid (11.3\%), which contain 20 carbons. Other oils used for biodiesel production have a low percentage of acids with similar chains and thus show lower viscosity index. Furthermore, M. pubescens oil has a few fatty acids with two degrees of unsaturation, such as linoleic acid (3.7\%), which is abundant in soybean (51.04\% to $55.4 \%)$ and sunflower oils $(51.17 \%$ to $52.01 \%)$ (Table 1$)$.

The density of $M$. pubescens oil $\left(0.8796 \mathrm{~g} \cdot \mathrm{cm}^{-3}\right)$ was lower than that found in the literature for soybean $(0.9185$ to $\left.0.931 \mathrm{~g} \cdot \mathrm{cm}^{-3}\right)$, rapeseed $\left(0.9145 \mathrm{~g} \cdot \mathrm{cm}^{-3}\right)$, sunflower $\left(0.9169\right.$ to $\left.0.932 \mathrm{~g} \cdot \mathrm{cm}^{-3}\right)$, palm $\left(0.917\right.$ to $\left.0,928 \mathrm{~g} \cdot \mathrm{cm}^{-3}\right)$, cotton $\left(0.910\right.$ to $\left.0.9148 \mathrm{~g} \cdot \mathrm{cm}^{-3}\right)$, corn $\left(0,9167 \mathrm{~g} \cdot \mathrm{cm}^{-3}\right)$, and canola oils $\left(0.917 \mathrm{~g} \cdot \mathrm{cm}^{-3}\right)$, and animal fats $(0.909$ to $0.91 \mathrm{~g} \cdot \mathrm{cm}^{-3}$ ) (Table 4). The density is influenced by the carbon chain length, number of unsaturated bonds in the fatty acids present in the oil, and also the temperature (Esteban et al., 2012; Martinez et al., 2014).

The refractive index of $M$. pubescens oil $(1.3348 \mathrm{nD})$ is lower than that reported in the literature for soybean (1.4671 and $1.4680 \mathrm{nD})$, sunflower (1.4668 and $1.4679 \mathrm{nD})$, corn $(1.4657 \mathrm{nD})$, and castor oils (1.4792 $\mathrm{nD})$, and higher than that of linseed oil (1.2 $\mathrm{nD}$ ) (Table 4). The refractive index depends on the degree of unsaturation of the fatty acids of the oil, the oxidized compounds and polymers present, and also varies according to the heat treatment the oil undergoes. Each type of oil, therefore, shows a different refractive index (Ghanei et al., 2011; Jorge et al., 2005; Moradi et al., 2012; Santos et al., 2013).

The ash content found in M. pubescens oil was $0.012 \%$, which is similar to that reported in the literature for palm $(0.01 \%)$ and souari nut oils $(0.01 \%)$, and less than that found in babassu oil (0.03\%) (Costa Neto et al., 2000).

\subsection{Transesterification and Biodiesel Properties}

The transesterification reaction reduced the viscosity index of the oil. The index measured in the biodiesel produced $\left(29.62 \mathrm{~mm}^{2} \cdot \mathrm{s}^{-1}\right)$ was lower than that in the oil $\left(101.46 \mathrm{~mm}^{2} \cdot \mathrm{s}^{-1}\right)$. However, the viscosity index is still higher than that determined by the ANP and ASTM D6751. It is also higher than that found in biodiesel produced from other sources such as soybean $\left(3.97\right.$ and $\left.4.04 \mathrm{~mm}^{2} \cdot \mathrm{s}^{-1}\right)$, sunflower $\left(4.03\right.$ and $\left.4.55 \mathrm{~mm}^{2} \cdot \mathrm{s}^{-1}\right)$, castor $\left(15.3 \mathrm{~mm}^{2} \cdot \mathrm{s}^{-1}\right)$, animal fat $\left(4.65 \mathrm{~mm}^{2} \cdot \mathrm{s}^{-1}\right)$, canola $\left(4.34\right.$ and $\left.4.41 \mathrm{~mm}^{2} \cdot \mathrm{s}^{-1}\right)$, and cotton oils (4.0 and 4.06) (Table $5)$. 
Table 5. Characterization of biodiesel M. pubescens and comparison with others sources

\begin{tabular}{lllll}
\hline Biodiesel & $\begin{array}{l}\text { Viscosity } 40^{\circ} \mathrm{C} \\
\left(\mathrm{mm}^{2} \cdot \mathrm{s}^{-1}\right)\end{array}$ & $\begin{array}{l}\text { Specific mass } 20^{\circ} \mathrm{C} \\
\left(\mathrm{g} \cdot \mathrm{cm}^{-3}\right)\end{array}$ & $\begin{array}{l}\text { Acidity index } \\
\left(\mathrm{mg} \mathrm{KOH} \cdot \mathrm{g}^{-1}\right)\end{array}$ & $\begin{array}{l}\text { Saponification } \\
\left(\mathrm{mg} \mathrm{KOH} \cdot \mathrm{g}^{-1}\right)\end{array}$ \\
\hline M. pubescens & $29.62( \pm 0.142)$ & $0.8484( \pm 0.015)$ & $0.752( \pm 0.151)$ & $148.89( \pm 3.567)$ \\
Standard ANP & $3.0-6.0^{(1)}$ & $0.850-0.900^{(1)}$ & $0.5(\mathrm{max})^{(1)}$ & - \\
ASTM D6751 & $1.9-6.0^{(10)}$ & - & $0.5(\max )^{(10)}$ & - \\
Diesel oil & - & $0.838^{(7)}$ & - & - \\
Soybean & $4.04^{(2)} ; 3.97^{(3)}$ & $0.8845^{(3)}$ & $0.16^{(3)} ; 0.24^{(2)}$ & $190.7^{(2)} ; 194.61^{(9)}$ \\
Palm & $4.28^{(3)}$ & $0.8746^{(3)}$ & $0.13^{(3)}$ & $205.0^{(9)}$ \\
Cotton & $4.0^{(6)} ; 4.06^{(3)}$ & $0.885^{(6)} ; 0.883^{(3)}$ & $0.09^{(3)}$ & - \\
Sunflower & $4.55^{(2)} ; 4.03^{(3)}$ & $0.8840^{(3)}$ & $0.14^{(3)} ; 0.34^{(2)}$ & $186.0^{(2)} ; 190.23^{(9)}$ \\
Castor oil & $15.3^{(5)}$ & $0.925^{(5)}$ & $1.03^{\mathrm{a}} ; 1.60^{\mathrm{a}(5)}$ & - \\
Reused oil & - & - & $3.3^{\mathrm{a}} ; 15.7^{\mathrm{a}(8)}$ & - \\
Beef tallow & $4.65^{(4)}$ & - & - & - \\
Canola & $4.34^{(3)} ; 4.41^{(4)}$ & $0.8828^{(3)}$ & $0.16^{(3)} ; 0.32^{(2)}$ & - \\
Rapeseed & - & - & - & $185.0^{(2)} ; 197.07^{(9)}$
\end{tabular}

Note. References: ${ }^{(1)}$ ANP 45/2014; ${ }^{(2)}$ Martínez et al. (2014); ${ }^{(3)}$ Alptekin and Canakci (2008); ${ }^{(4)}$ Farahani et al. (2011); ${ }^{(5)}$ Canoira et al. (2010); ${ }^{(6)}$ Rakopoulos et al. (2015); ${ }^{(7)}$ Pereira et al. (2012); ${ }^{(8)}$ Jacobson et al. (2008); ${ }^{(9)}$ Gopinath et al. (2009); ${ }^{(10)}$ ASTM D6751. ${ }^{\text {a }}$ Varies according changes of temperature conditions and quantities of catalyst and alcohol.

Some methods, however, may reduce the viscosity index of biodiesel, such as an admixture of different raw materials in its production, as well as admixture of ready-to-use biodiesel with diesel fuel in suitable ratios and fuel pre-heating prior to using it. (Atmanli et al., 2015; Blin et al., 2013; Mata et al., 2011; Rakopoulos et al., 2015).

The transesterification also reduced the density of $M$. pubescens oil from $0.8796 \mathrm{~g} \cdot \mathrm{cm}^{-3}$ to $0.8484 \mathrm{~g} \cdot \mathrm{cm}^{-3}$ in biodiesel. In spite of being a value higher than that found in mineral diesel $\left(0.838 \mathrm{~g} \cdot \mathrm{cm}^{-3}\right)$, it is lower than that determined by the ANP and suggested for biodiesel from other sources (Table 5).

The biodiesel acidity level $\left(0.752 \mathrm{mg} \mathrm{KOH} \cdot \mathrm{g}^{-1}\right)$ was higher than the limit established by the ANP and the ASTM D6751, which suggesta maximum of $0.5 \mathrm{mg} \mathrm{KOH} \cdot \mathrm{g}^{-1}$. The level found is also higher compared with biodiesel produced from other sources, such as soybean $\left(0.16\right.$ and $\left.0.24 \mathrm{mg} \mathrm{KOH} \cdot \mathrm{g}^{-1}\right)$, canola $\left(0.16\right.$ to $\left.0.32 \mathrm{mg} \mathrm{KOH} \cdot \mathrm{g}^{-1}\right)$, cotton $\left(0.09 \mathrm{mg} \mathrm{KOH} \cdot \mathrm{g}^{-1}\right)$, and sunflower oils $\left(0.14\right.$ and $\left.0.34 \mathrm{mg} \mathrm{KOH} \cdot \mathrm{g}^{-1}\right)$. However, it was lower than that found in biodiesel produced from reused oil $\left(3.3\right.$ to $\left.15.7 \mathrm{mg} \mathrm{KOH} \cdot \mathrm{g}^{-1}\right)$ and castor oil (1.03 to $\left.1.60 \mathrm{mg} \mathrm{KOH} \cdot \mathrm{g}^{-1}\right)$ (Table 5). The acidity level of biodiesel is related to the biodiesel production process. Transesterification using oils from the same source, but modification of reaction conditions such as temperature, stirring, molar ratio between catalyst and alcohol, results in biodiesel with different acidity levels (Canoira et al., 2010; Jacobson et al., 2008; Martinez et al., 2014).

There are no official regulations for saponification values in biodiesel. The saponification value of biodiesel from $M$. pubescens oil was $148.89 \mathrm{mg} \mathrm{KOH} \cdot \mathrm{g}^{-1}$, which is below the saponification values reported in biodiesel produced from different sources of oil such as soybean (190.7 $\left.\mathrm{mg} \mathrm{KOH} \cdot \mathrm{g}^{-1}\right)$, rapeseed (185.0 and $197.07 \mathrm{mg}$ $\left.\mathrm{KOH} \cdot \mathrm{g}^{-1}\right)$, sunflower $\left(186.0\right.$ and $\left.190.23 \mathrm{mg} \mathrm{KOH} \cdot \mathrm{g}^{-1}\right)$, and palm oil $\left(205.0 \mathrm{mg} \mathrm{KOH} \cdot \mathrm{g}^{-1}\right)($ Table 5).

In Brazil, it is tried to diversify the oil sources for the fabrication of biodiesel through the Brazilian National Program of Production and Use of Biodiesel, which also encourages the inclusion of family farming in the cultivation of these inputs with the goal of promoting social development. However, due to the variation in price and low availability of other raw materials, soybean oil remained the main source used in recent years (Santos Alves et al., 2017; César \& Batalha, 2010; Zonin et al., 2014). It is also necessary to consider that soy is an important foodstuffs, so it is imperative to find new oil plants with potential for biodiesel production and that do not represent sources of food, as the M. pubescens (No, 2011; Suarez et al., 2009).

Other studies must be carried out in order to verify the possibility of cultivation, economic and productive variables such as productivity per hectar and oil content per hectar, since these conditions have not yet been evaluated and this work verified that M. pubescens oil has physical and chemical properties appropriate for biodiesel production, with the exception of the peroxide value. Therefore, further studies too should be carried 
out to evaluate other extraction processes to achieve suitable peroxide values and allow for a better use of seeds. Chromatographic analysis showed that the qualitative composition of fatty acids in the oil is similar to that of other oils used for biodiesel production. M. pubescens oil is suitable for producing biodiesel, however, transesterification conditions should be evaluated to obtain biodiesel with more suitable physical and chemical properties.

\section{Acknowledgements}

We thank the Foundation for Research Support of Minas Gerais and to Prof. Flaviano Oliveira Silvério of the Institute of Agrarian Sciences of the Federal University of Minas Gerais.

\section{References}

Adams, R. P. (2007). Identification of essential oil components by gas chromatography/mass spectrometry (4th ed., p. 804). Illinois USA: Allured Publishing Corporation, Carol Stream.

Almeida, D. T., Nunes, I. L., Conde, P. L., Rosa, R. P. S., Rogerio, W. F., \& Machado, E. R. (2013). A quality assessment of crude palm oil marketed in Bahia, Brazil. Grasas y Aceites, 64, 387-394. https://doi.org/ $10.3989 /$ gya. 118412

Alptekin, E., \& Canakci, M. (2008). Determination of the density and the viscosities of biodiesel-diesel fuel blends. Renewable Energy, 33, 2623-2630. https://doi.org/10.1016/j.renene.2008.02.020

American Oil Chemists' Society. (1988). Official methods and recommended practices (5th ed.). Champaign.

Anonymous. (2015). Resolução ANP $n^{\circ}$ 45, de 25 de Agosto de 2014. Diário Oficial da União 26 de Agosto de 2014. Retrieved September 14, 2015, from http://nxt.anp.gov.br/nxt/gateway.dll/leg/resolucoes_anp/2014/ agosto/ranp\%2045\%20-\%202014.xml

Association of Official Analytical Chemistry. (2012). Official methods of analyses (19th ed.). Gaithersburg.

ASTM D6751. (2015). Standard Specification for Biodiesel Fuel Blend Stock (B100) for Middle Distillate Fuels. ASTM International. West Conshohocken, PA. https://doi.org/10.1520/D6751-15CE01

Atmanli, A., Ileri, E., Yuksel, B., \& Yilmaz, N. (2015). Extensive analyses of diesel-vegetable oil-n-butanol ternary blends in a diesel engine. Applied Energy, 145, 155-162. https://doi.org/10.1016/j.apenergy. 2015.01.071

Bera, D., Lahiri, D., \& Nag, A. (2006). Studies on a natural antioxidant for stabilization of edible oil and comparison with synthetic antioxidants. Journal of Food Engineering, 74, 542-545. https://oi.org/10.1016/ j.jfoodeng.2005.03.042

Blin, J., Brunschwiga, C., Chapuisa, A., Changotadea, O., Sidibea, S., Noumia, E., \& Girard, P. (2013). Characteristics of vegetable oils for use as fuel in stationary diesel engines-Towards specifications for a standard in west Africa. Renewable and Sustainable Energy Reviews, 22, 580-597. https://doi.org/ 10.1016/j.rser.2013.02.018

Canoira, L., Galeán, J. G., Alcántara, R., Lapuerta, M., \& García Contreras, R. (2010). Fatty acid methyl esters (FAMEs) from castor oil: Production process assessment and synergistic effects in its properties. Renewable Energy, 35, 208-217. https://doi.org/10.1016/j.renene.2009.05.006

Castro, W., Perez, J. M., Erhan, S. Z., \& Caputo, F. (2006). A study of the oxidation and wear properties of vegetable oils: Soybean oil without additives. Journal of the American Oil Chemists' Society, 83, 47-52. https://doi.org/10.1007/s11746-006-1174-2

César, A. S., \& Batalha, M. O. (2010). Biodiesel production from castor oil in Brazil: A difficult reality. Energy Policy, 38, 4031-4039. https://doi.org/10.1016/j.enpol.2010.03.027

Coelho, M. F. B., Sanches, V. L., \& Azevedo, R. A. B. (2012). Emergência de sementes de timbó em diferentes condições de luz. Revista Caatinga, 25, 194-198.

Costa Neto, P. R., Rossi, L. F. S., Zagonel, G. F., \& Ramos, L. P. (2000). Produção de biocombustível alternativo ao óleo diesel através da transesterificação de óleo de soja usado em frituras. Química Nova, 23, 531-537. https://doi.org/10.1590/S0100-40422000000400017

Esteban, B., Riba, J. R., Baquero, G., Rius, A., \& Puig, R. (2012). Temperature dependence of density and viscosity of vegetable oils. Biomass Bioenergy, 42, 164-171. https://doi.org/10.1016/j.biombioe.2012. 03.007 
Farahani, M., Pagé, D. J. Y. S., \& Turingia, M. P. (2011). Sedimentation in biodiesel and ultra low sulfur diesel fuel blends. Fuel, 90, 951-957. https://doi.org/10.1016/j.fuel.2010.10.046

Ghanei, R., Moradi, G. R., Taherpourkalantari, R., \& Arjmandzadeh, E. (2011). Variation of physical properties during transesterification of sunflower oil to biodiesel as an approach to predict reaction progress. Fuel Processing Technology, 92, 1593-1598. https://doi.org/10.1016/j.fuproc.2011.04.003

Goodrum, J. W., Geller, D. P., \& Adams, T. T. (2003). Rheological characterization of animal fats and their mixtures with 2 fuel oil. Biomass Bioenergy, 24, 249-256. https://doi.org/10.1016/S0961-9534(02)00136-8

Gopinath, A., Puhan, S., \& Nagarajan, G. (2009). Theoretical modeling of iodine value and saponification value of biodiesel fuels from their fatty acid composition. Renewable Energy, 34, 1806-1811. https://doi.org/ 10.1016/j.renene.2008.11.023

IAL (Instituto Adolfo Lutz). (2008). Métodos Físico-Químicos para Análise de Alimentos (1st ed., Digital). Retrieved July 3, 2015, from http:/www.ial.sp.gov.br/index.php?option=com_remository\&Itemid=0\&func $=$ select\&id=1\&orderby $=1 \&$ page $=1$

Jacobson, K., Gopinath, R., Meher, L. C., \& Dalai, A. K. (2008). Solid acid catalyzed biodiesel production from waste cooking oil. Applied Catalysis B: Environmental, 85, 86-91. https://doi.org/10.1016/j.apcatb. 2008.07.005

Jorge, N., Soares, B. B. P., Lunardi, V. M., \& Malacrida, C. R. (2005). Alterações físico-químicas dos óleos de girassol, milho e soja em frituras. Química Nova, 28, 947-951. https://doi.org/10.1590/S0100-4042200500 0600003

Knothe, G. (2002). Structure Indices in FA Chemistry. How Relevant Is the Iodine Value? Journal of the American Oil Chemists'Society, 79, 847-854. https://doi.org/10.1007/s11746-002-0569-4

Kwiecien, J., Hájek, M., \& Skopal, F. (2009). The effect of the acidity of rapeseed oil on its transesterification. Bioresource Technology, 100, 5555-5559. https://doi.org/10.1016/j.biortech.2009.06.002

Martínez, G., Sánchez, N., Encinar, J. M., \& González, J. F. (2014). Fuel properties of biodiesel from vegetable oils and oil mixtures. Influence of methyl esters distribution. Biomass and Bioenergy, 63, 22-32. https://doi.org/10.1016/j.biombioe.2014.01.034

Mata, T. M., Cardoso, N., Ornelas, M., Neves, S., \& Caetano, N. S. (2011). Evaluation of two purification methods of biodiesel from beef tallow, pork lard, and chicken fat. Energy and Fuels, 25, 4756-4762. https://doi.org/10.1021/ef2010207

Melero, J. A., Clavero, M. M., Calleja, G., García, A., Miravalles, R., \& Galindo, T. (2010). Production of biofuels via the Catalytic Cracking of Mixtures of Crude Vegetable Oils and nonedible animal fats with vacuum gas oil. Energy and Fuels, 24, 707-717. https://doi.org/ 10.1021/ef900914e

Mendow, G., Veizaga, N. S., Sanchez, B. S., \& Querini, C. A. (2011). Biodiesel production by two-stage transesterification with ethanol. Bioressorce Technology, 102, 10407-10413. https://oi.org/10.1016/ j.biortech.2011.08.052

Moradi, G. R., Dehghani, S., \& Ghanei, R. (2012). Measurements of physical properties during transesterification of soybean oil to biodiesel for prediction of reaction progress. Energy Conversion and Management, 61, 67-70. https://doi.org/10.1016/j.enconman.2012.03.015

No, S. Y. (2011). Inedible vegetable oils and their derivatives for alternative diesel fuels in CI engines: A review. Renewable and Sustainable Energy Reviews, 15, 131-149. https://doi.org/10.1016/j.rser.2010.08.012

Oliveira, D. M., Ongaratto, D. P., Fontoura, L. A. M., Naciuk, F. F., Santos, V. O. B., Kunz, J. D., ... Samios, D. (2013). Obtenção de biodiesel por transesterificação em dois estágios e sua caracterização por cromatografía gasosa: óleos e gorduras em laboratório de química orgânica. Química Nova, 36, 734-737. https://doi.org/10.1590/S0100-40422013000500021

Pantoja, S. S., Conceição, L. R. V., Costa, C. E. F., Zamian, J. R., \& Rocha Filho, G. N. (2013). Oxidative stability of biodiesels produced from vegetable oils having different degrees of unsaturation. Energy Conversion and Management, 74, 293-298. https://doi.org/10.1016/j.enconman.2013.05.025

Pereira, C. M. P., Hobuus, C. B., Maciel, J. V., Ferreira, L. R., Del Pino, F. B., \& Mesko, M. F. (2012). Biodiesel renovável derivado de microalgas: Avanços e perspectivas tecnológicas. Química Nova, 35, 2013-2018. https://doi.org/10.1590/S0100-40422012001000022 
Quinchia, L. A., Delgado, M. A., Velencia, C., Franco, J. M., \& Gallegos, C. (2010). Viscosity modification of different vegetable oils with EVA copolymer for lubricant applications. Industrial Crops and Products, 32, 607-612. https://doi.org/10.1016/j.indcrop.2010.07.011

Rakopoulos, D. C., Rakopoulos, C. D., \& Giakoumis, E. G. (2015). Impact of properties of vegetable oil, bio-diesel, ethanol and n-butanol on the combustion and emissions of turbocharged HDDI diesel engine operating under steady and transient conditions. Fuel, 156, 1-19. https://doi.org/10.1016/j.fuel.2015.04.021

Santos Alves, C. E., Belarmino, L. C., \& Padula, A. D. (2017). Feedstock diversification for biodiesel production in Brazil: Using the Policy Analysis Matrix (PAM) to evaluate the impact of the PNPB and the economic competitiveness of alternative oilseeds. Energy Policy, 109, 297-309. https://doi.org/10.1016/j.enpol. 2017.07.009

Santos, R. C. R., Vieira, R. B., \& Valentini, A. (2013). Monitoring the conversion of soybean oil to methyl or ethyl esters using the refractive index with correlation gas chromatography. Microchemical Journal, 109, 46-50. https://doi.org/10.1016/j.microc.2012.05.001

Siddique, B. M., Ahmad, A., Ibrahim, M. H., Hena, S., Rafatullahb, M., \& Omar, A. K. M. (2010). Physico-chemical properties of blends of palm olein with other vegetable oils. Grasas y Aceites, 61, 423-429. https://doi.org/10.3989/gya.010710

Sidibé, S. S., Blin, J., Vaitilingom, G., \& Azoumah, Y. (2010). Use of crude filtered vegetable oil as a fuel in diesel engines state of the art: Literature review. Renewable and Sustainable Energy Reviews, 14, 2748-2759. https://doi.org/10.1016/j.rser.2010.06.018

Suarez, P. A. Z., Santos, A. L. F., Rodrigues, J. P., \& Alves, M. B. (2009). Biocombustíveis a partir de óleos e gorduras: Desafios tecnológicos para viabilizá-los. Química Nova, 32, 768-775. https://dx.doi.org/10.1590/ S0100-40422009000300020

Toscano, G., Riva, G., Pedretti, E. F., \& Duca, D. (2012). Vegetable oil and fat viscosity forecast models based on iodine number and saponification number. Biomass and Bioenrgy, 46, 511-516. https://doi.org/10.1016/ j.biombioe.2012.07.009

Zonin, V. J., Antunes, J. A. V., \& Jr, Leis, R. P. (2014). Multicriteria analysis of agricultural raw materials: A case study of BSBIOS and PETROBRAS BIOFUELS in Brazil. Energy Policy, 67, 255-263. https://doi.org/10.1016/j.enpol.2013.12.029

\section{Copyrights}

Copyright for this article is retained by the author(s), with first publication rights granted to the journal.

This is an open-access article distributed under the terms and conditions of the Creative Commons Attribution license (http://creativecommons.org/licenses/by/4.0/). 